\title{
Validity of the Katz Index to assess activities of daily living by informants in neuropathological studies
}

\author{
Validade do Índice de Katz para avaliar atividades básicas de vida \\ diária por informantes em estudos neuropatológicos \\ Validez del Índice de Katz para evaluar las actividades básicas de \\ vida diaria por informantes en estudios neuropatológicos
}

Renata Eloah de Lucena Ferretti-Rebustini ${ }^{1,2}$, Marcos Alencar Abaide Balbinotti ${ }^{2}$, Wilson Jacob-Filho ${ }^{3,4}$, Flávio Rebustini ${ }^{2,5}$, Claudia Kimie Suemoto ${ }^{3,4}$, Carlos Augusto Gonçalves Pasqualuccii, ${ }^{3,6}$, José Marcelo Farfel ${ }^{3,4}$, Renata Elaine Paraízo Leite ${ }^{3}$, Lea Tenenholz Grinberg ${ }^{3,7}$, Ricardo Nitrini ${ }^{3,8}$

\author{
${ }^{1}$ Universidade de São Paulo, Escola de \\ Enfermagem, Departamento de Enfermagem \\ Médico-Cirúrgia, São Paulo, SP, Brazil. \\ ${ }^{2}$ University of Quebec in Trois-Rivières, \\ Department of Psychology, Laboratory \\ of Psychometric and Experimental \\ Methods, Trois-Rivière, QC, Canada. \\ ${ }^{3}$ Universidade de São Paulo, Faculdade de \\ Medicina, Laboratório de Fisiopatologia no \\ Envelhecimento, São Paulo, SP, Brazil. \\ ${ }^{4}$ Universidade de São Paulo, \\ Faculdade de Medicina, Disciplina de \\ Geriatria, São Paulo, SP, Brazil. \\ ${ }^{5}$ Universidade Estadual Paulista "Júlio de \\ Mesquita Filho", Instituto de Biociências, \\ Laboratório de Estudos e Pesquisas em \\ Psicologia do Esporte, Rio Claro, SP, Brazil. \\ ${ }^{6}$ Serviço de Verificação de Óbitos da \\ Capital, São Paulo, SP, Brazil. \\ ${ }^{7}$ University of California, Department \\ of Neurology, Memory and Aging \\ Center, San Francisco, California, \\ CA, Unites States of America. \\ ${ }^{8}$ Universidade de São Paulo, Faculdade \\ de Medicina, Departamento de \\ Neurologia, São Paulo, SP, Brazil.
}

\begin{abstract}
Objective: To analyze the evidences of construct validity of the Katz Index for the retrospective assessment of activities of daily living (ADL) by informants, to assist neuropathological studies in the elderly. Method: A cross-sectional study analyzed the functional ability of ADL measure by the Katz Index, of 650 cases randomly selected from the Brazilian Brain Bank of the Ageing Brain Study Group (BBBABSG) database. Sample was divided in two subsamples for the analysis $(\mathrm{N}=325$, each) and then stratified according to cognitive decline assessed by the Clinical Dementia Rating Scale (CDR). Factor analyses with calculations of internal consistency and invariance were performed. Results: Factor analysis evidenced a unidimensional instrument with optimal internal consistency, in all subgroups. Goodness of fit indices were obtained after two treatments of covariance, indicating adequacy of the scale for assessing ADL by informants. The scale is invariant to cognitive decline meaning that it can be used for subjects with or without cognitive impairment. Conclusion: Katz Index is valid for the retrospective assessment of basic ADL by informants, with optimal reliability.
\end{abstract}

\section{DESCRIPTORS}

Activities of Daily Living; Aging; Proxy; Psychometrics; Validation Studies.
Corresponding author:

Renata Eloah de Lucena Ferretti-Rebustini

Av. Dr. Enéas de Carvalho Aguiar, 419 -

Cerqueira César

CEP 05403-000 - São Paulo, SP, Brazil

reloah@usp.br
Received: 05/29/2015

Approved: 07/15/2015 


\section{INTRODUCTION}

Global prevalence of dementia is increasing and estimates indicate that in 2050 there will be 135 million of people worldwide suffering from dementia ${ }^{(1)}$. The higher prevalence rates are in Latin America (8.7\%)(2), probably due to the increased occurrence of risk factors in these countries ${ }^{(3)}$. Characterized by progressive impairment in cognition, in behavior and in functional ability to independent living ${ }^{(2,4-5)}$, the cause of dementia is still unknown ${ }^{(4)}$. Thus, postmortem studies can play and important role in helping elucidate the pathways of dementia physiopathology.

Clinicopathological studies of dementia are more important than brain autopsy only, once the correlations of clinical data with the brain autopsy findings are precious. These types of studies have some limitations regarding autopsy donations and clinical data acquisition. Despite the limitations, clinicopathological studies are worthy. After death, in cases where clinical data are not available either because the dementia diagnosis was not established in life or because clinical data is missing, the informant interview can be the only source of information.

Considering the value of functional status in the diagnosis of dementia ${ }^{(6)}$, assessing the patient's ability to perform independently activities of daily living (ADL) is extremely important to clinicopathological diagnosis after death. Information about the performance of the patient to ADL can be gathered with a close knowledgeable informant by using assessment scales. The only problem is that as far as it is known, no functional assessment scales have been developed to be used in postmortem studies.

In the last decade, the Brazilian Brain Bank of the Ageing Brain Study Group (BBBABSG) has been collecting brains for clinicopathological analysis and functional data related to performance in ADL prior to death is obtained, retrospectively, by the use of the Katz Index ${ }^{(7)}$. The instrument assesses six basic ADL: bathing, dressing, toileting, continence, transference and feeding ${ }^{(8-9)}$. Since the scale development, some evidences of validity were verified; with data concerning psychometric information mostly limited to reliability and validity analysis or to item difficulty hierarchy ${ }^{(10-16)}$.

To date, no study has described structural factors of the scale and psychometric properties for its use with informants in postmortem settings; therefore, the aim of the present study was to analyze the psychometric properties of the Katz Index for the retrospective assessment of basic ADL by informants in postmortem, to assist neuropathological studies.

\section{METHOD}

\section{StUdD DESIGN AND SOURCE OF CASES}

A cross-sectional study was performed where secondary data from the Brazilian Brain Bank of the Aging Brain Study Group (BBBABSG) database were analyzed. The BB$\mathrm{BABSG}$ is a tissue bank and its procedure has been approved by local ethical committee ( $\mathrm{N}^{\circ}$ 458.272) and described elsewhere ${ }^{(17-18)}$. The study was approved by the Research Ethics Committee for the Hospital das Clínicas da Faculdade de
Medicina da Universidade de São Paulo (No 942/04). Written informed consent was obtained from the next-of-kin on behalf of the participant, before the interview.

\section{Study SAMPLE AND PARTICIPANT SELECTION}

From the original sample of 3.000 valid cases included from 2005 to 2012, 650 cases were randomly selected by an online program (http://www.randomizer.org/). The random sampling procedure was adopted to minimize the investigator's interference in the case selection. Sample size was estimated to obtain a factor loading of $0.30^{(19)}$.

\section{Study VARIABles}

The variables extracted from the BBBABSG database were age, gender, score of the Informant Questionnaire on Cognitive Decline of the Elderly (IQCODE), the score of the Clinical Dementia Rating Scale (CDR), and Katz Index scores (total and for each scale item). In the BBBABSG, these variables are gathered during a clinical interview ${ }^{(20)}$ with a knowledgeable informant and refer to the time prior to the subject's death. All of the informants reported having close contact (daily living) with the subject.

\section{Assessment of the Activities of Daily Living (ADL)}

During the BBBABSG clinical interview with the informant, a trained nurse investigated basic ADL by the Katz Index.

The Katz Index ${ }^{(7)}$ consists of a 6-item scale: bathing, dressing, toileting, transfer, continence and feeding ${ }^{(16)}$. The scale ranks subjects according to performance for each item and gives a total score corresponding to overall performance ${ }^{(7)}$. Several forms of interpretation have been proposed $^{(7-11,21-25)}$. The BBBABSG uses an adapted scoring method that attributes a value for each item as follows: $1-$ performs the activity without any assistance (independent); 0.5 - performs the activity with partial assistance (partially dependent); 0 - needs full assistance to perform the activity (dependent). The global score varies from 0 to 6 , with six being the most independent. Subjects are classified into three levels of dependency: independent ( $\geq 6$ points), partially dependent ( $3-5$ points) and dependent $(\leq 2 \text { points })^{(21)}$. The 3 -point scoring system facilitates classical factor analysis, as binary data can cause bias in the standard analyses ${ }^{(19)}$.

\section{Statistical anAlysis}

Before the analysis, sample was divided in two halves: subsample $A(\mathrm{~N}=325)$ and subsample $\mathrm{B}(\mathrm{N}=325)$. The evidence of construct validity was observed by Exploratory Factor Analysis (EFA) and Confirmatory Factor Analysis (CFA). EFA and Reliability analysis were conducted in Subsample A and CFA in subsample B. To test whether there were differences in construct validity according to the existence of cognitive decline prior to death we stratified subsample A in two groups: without cognitive decline (CDR 0$)$ and with cognitive decline ( $C D R \geq 0.5)$.

For the EFA we used the weighted least squares method to minimize residuals with oblimin rotation and 
extraction of factors load $\geq 0.40^{(19,26)}$. A Kaiser-Meyer-Olkin $(\mathrm{KMO}) \geq 0.70$ and a significant Bartlett Index represented a measure of sample adequacy ${ }^{(19)}$. Model fit was analyzed by inspecting fit indexes, modification indexes (MI) and correlational residuals ${ }^{(19,26)}$. Adequacy of a good model fit were: non-significant Chi-squared $\left(X^{2}\right)$; goodness of fit index $(\mathrm{GFI}) \geq 0.95$; adjusted goodness of fit index $(\mathrm{AGFI}) \geq 0.95$; standardized root mean square residual $(\mathrm{SRMR}) \leq 0.08$; comparative fit index $(\mathrm{CFI}) \geq 0.95$; Tucker-Lewis coefficient $(\mathrm{TLI}) \geq 0.95$; normed fit index $(\mathrm{NFI}) \geq 0.95$ and root mean square error of approximation (RMSEA) $\leq 0.07$. MI was observed to determine which errors could be controlled ${ }^{(19,26)}$. Invariance ${ }^{(19)}$ of the scale according to cognitive decline was analyzed by comparing the scale construct in two groups (with or without cognitive decline).

To test reliability we used the Cronbach's alpha $(\alpha)$. Good general internal consistency was observed when the $\alpha$-value was $>0.70$. Item-item correlation was used to determine redundancy among items $(>0.80)$, and corrected item-total correlation was observed to determine the discriminatory power of the item $(<0.30)^{(19)}$.

For the analysis, the IBM Statistical Software for the Social Sciences (SPSS v.21), with AMOS package, was used. The Stats Tools Package of Excel was used for the analysis of invariance. All tests were two-sided, and the significance level was set at 0.05 .

\section{RESULTS}

The total sample consisted of 650 participants who were mostly men $(55.3 \%)$ with a mean age of $68.7 \pm 11.3$ years. Women were older than the men $(70.7 \pm 11.8$ vs. $67.1 \pm 10.7$ years; $p<0.01)$. Subjects were mostly independent (76.5\%). Only 7.7\% were partially dependent, and $15.8 \%$ were totally dependent. Men were more independent than women, with a mean global Katz Index score of $5.4 \pm 1.6$ points $(95 \%$ CI: $5.2-5.5)$ compared with $4.9 \pm 2.0$ points for women ( $95 \%$ CI: $4.7-5.1)$. This difference was statistically significant $(p<0.001)$. Concerning the cognitive decline, 513 (78,8\%) were CDR 0 and 21,2\% had CDR varying from 0.5 to 3 . The mean IQCODE of the sample was $3.19 \pm 0.44$ points. Comparisons of sex distribution, age, years of schooling, Katz and IQCODE in each subsample is presented in Table 1.

\section{EXPLORATORY FACTOR ANALYSIS}

A ratio of approximately 54 cases per item was used ( 325 cases of subsample A and 6 items). Table 1 presents the results of EFA for the whole subsample (total) and according to cognitive decline. The Kaiser-Meyer-Olkin and the Bartlett's sphericity test showed the sample adequacy of the factor analysis to be performed in all groups. We observed the same evidence of construct structure (one-dimensional instrument) and reliability in all groups. Only one factor was extracted (named independence to ADL) being responsible for more than $80 \%$ of construct, in all groups.

It was observed the existence of strong range of itemitem correlations $(>0.85)$, very small correlation matrix determinant $(<0.00001)$, higher values of communalities
$(>0.95)$ and strong standardized item-total correlations $(>0.90)$. This all are indicatives of collinearity.

Table 1 - Sample characteristics according to selected variables São Paulo, SP, Brazil, 2005 - 2013.

\begin{tabular}{lccc}
\hline & Total & $\begin{array}{c}\text { Subsample } \\
\text { A }\end{array}$ & $\begin{array}{c}\text { Subsample } \\
\text { B }\end{array}$ \\
\hline $\mathrm{N}$ & 650 & 325 & 325 \\
Gender Male [n(\%)] & $360(55.4)$ & $183(56.3)$ & $177(54.5)$ \\
Female [n(\%)] & $290(44.6)$ & $142(43.7)$ & $148(45.5)$ \\
Age (mean \pm SD) & $68.7 \pm$ & $69.2 \pm$ & $68.1 \pm$ \\
Years of schooling & 11.3 & 11.4 & 11.2 \\
(mean \pm SD) & $4.4 \pm 3.5$ & $3.891 \pm$ & $4.4 \pm 3.4$ \\
IQCODE (mean \pm SD) & $3.2 \pm 0.4$ & $3.2 \pm 0.5$ & $3.1 \pm 0.4$ \\
Katz Index (mean \pm SD) & $5.3 \pm 1.7$ & $5.3 \pm 1.7$ & $5.2 \pm 1.8$ \\
Clinical Dementia Rating Scale [n(\%)] & & \\
CDR 0 & $512(78.8)$ & $247(76.0)$ & $265(81.5)$ \\
CDR 0.5 & $43(6.6)$ & $20(6.2)$ & $23(7.1)$ \\
CDR 1 & $36(5.5)$ & $21(6.5)$ & $15(4.6)$ \\
CDR 2 & $23(3.5)$ & $14(4.3)$ & $9(2.8)$ \\
CDR 3 & $36(5.5)$ & $23(7.1)$ & $13(4.0)$ \\
\hline
\end{tabular}

Table 2 - Exploratory Factor Analysis of Katz Index, according to cognitive impairment - São Paulo, SP, Brazil, 2005-2013.

\begin{tabular}{|c|c|c|c|}
\hline & Total & $\begin{array}{l}\text { Without } \\
\text { cognitive } \\
\text { Impairment* } \\
(n=247)\end{array}$ & $\begin{array}{c}\text { With } \\
\text { Cognitive } \\
\text { Impairment* } \\
(n=78)\end{array}$ \\
\hline $\begin{array}{l}\text { Gender } \\
\text { Male/ Female (n) }\end{array}$ & & 152/ 95 & $31 / 47$ \\
\hline $\begin{array}{l}\text { Age } \\
(\text { mean } \pm \text { SD })\end{array}$ & & $66.92 \pm 10.68$ & $76.52 \pm 10.61$ \\
\hline $\begin{array}{l}\text { Years of } \\
\text { schooling }\end{array}$ & & $4.19 \pm 3.84$ & $2.94 \pm 2.99$ \\
\hline $\begin{array}{l}\text { IQCODE } \\
(\text { mean } \pm \text { SD })\end{array}$ & & $3.0 \pm 0.4$ & $3.9 \pm 0.6$ \\
\hline $\begin{array}{l}\text { Katz Index } \\
(\text { mean } \pm \text { SD) }\end{array}$ & & $5.8 \pm 0.6$ & $2.0 \pm 3.5$ \\
\hline
\end{tabular}

Exploratory

Factor Analysis

Range of item

correlation

$0.817-0.940 \quad 0.742-0.945$

$0.754-0.926$

$\%$ of Correlations

$>0.90$

Determinant

27

27

7

$\mathrm{KMO}$

$9.674^{-5}$

$7.405^{-5}$

0.001

0.918

0.880

0.905

$X^{2}$ Bartlett $_{(d f)}$ $2968.689_{(15)}{ }^{+}$

$2312.715_{(15)}^{+}$

$558.412_{(15)}^{+}$

Communalities

$0.822-0.950$

$0.721-0.975$

$0.777-0.916$

Factors extracted

Eigenvalue $>1$

$1^{\text {st }}$ factor

1

$2^{\text {nd }}$ factor

0.233

1

1

$\%$ variance

explained by

the $1^{\text {st }}$ factor

1

1

Factor loadings

$0.906-0.975$

$0.849-0.987$

$0.867-0.952$ 


\begin{tabular}{|c|c|c|c|}
\hline & Total & $\begin{array}{c}\text { Without } \\
\text { cognitive } \\
\text { Impairment* } \\
(n=247)\end{array}$ & $\begin{array}{c}\text { With } \\
\text { Cognitive } \\
\text { Impairment* } \\
(n=78)\end{array}$ \\
\hline \multicolumn{4}{|l|}{$\begin{array}{l}\text { Reliability } \\
\text { analysis }\end{array}$} \\
\hline $\begin{array}{l}\alpha \text {-Cronbach } \\
\text { (IC95\% } \\
\text { intraclass } \\
\text { correlation) }\end{array}$ & $\begin{array}{c}0.974(0.970- \\
0.978)\end{array}$ & $\begin{array}{c}0.966(0.959- \\
0.972)\end{array}$ & $\begin{array}{c}0.964(0.949- \\
0.975)\end{array}$ \\
\hline $\begin{array}{l}\text { Corrected Item- } \\
\text { Total Correlation }\end{array}$ & $0.892-0.958$ & $0.835-0.966$ & $0.863-0.934$ \\
\hline
\end{tabular}

*Without cognitive impairment $(\mathrm{CDR}=0)$; With Cognitive impairment $(\mathrm{CDR}>0.5)$; ${ }^{\dagger} \mathrm{p}<0.001\left(X^{2}\right.$ Bartlett). Note: (Subsample A; $\left.\mathrm{n}=325\right)$.

\section{CONFIRMATORY FACTOR ANALYSIS}

To reach goodness of fit in CFA the initial model required two adjustments (errors controlled): a) between bathing - dressing; b) between transfer - feeding. After their adjustment, the model reached goodness of fit indexes (Table 3). Structural Equation Model is presented in Figure 1.

Invariance analysis evidenced that the Katz Index is invariant to the existence of cognitive decline (Table 4). These results indicate that the scale can be used, independent of the existence of cognitive decline, and no normalization should be done for the scales in each group (with or without cognitive decline).

Thus, all these results indicate that in post-mortem, the Katz Index has good construct validity and goodness of fit to assess independence to basic ADL, despite the existence of cognitive decline.

Table 3 - Confirmatory Factor Analysis of Katz Index, according to cognitive impairment (Subsample B) - São Paulo, SP, Brazil, 2005-2013.

\begin{tabular}{lcc}
\hline & \multicolumn{2}{c}{ Katz Index } \\
& Initial & Adjusted \\
\hline Fitness Coefficients & 39.21 & 4.32 \\
$X^{2}$ & 9 & 7 \\
$D f$ & 0.00 & 0.74 \\
$p$-value & 4.36 & 0.62 \\
$X^{2}{ }_{(d f)}$ & 0.85 & 0.98 \\
GFI & 0.65 & 0.95 \\
AGFI & 0.93 & 0.99 \\
NFI & 0.91 & 1.00 \\
TLI rho & 0.95 & 1.00 \\
CFI & 0.290 & 0.009 \\
SRMR & 0.21 & 0.04 \\
RMSEA (Confidence Interval 90\%) & $(0.14-0.28)$ & $(0.00-1.01)$ \\
Number of Adjustments (errors & 2 & - \\
Controlled) & & \\
\hline
\end{tabular}

$X^{2}-$ Chi-squared; $D f$ - degrees of freedom

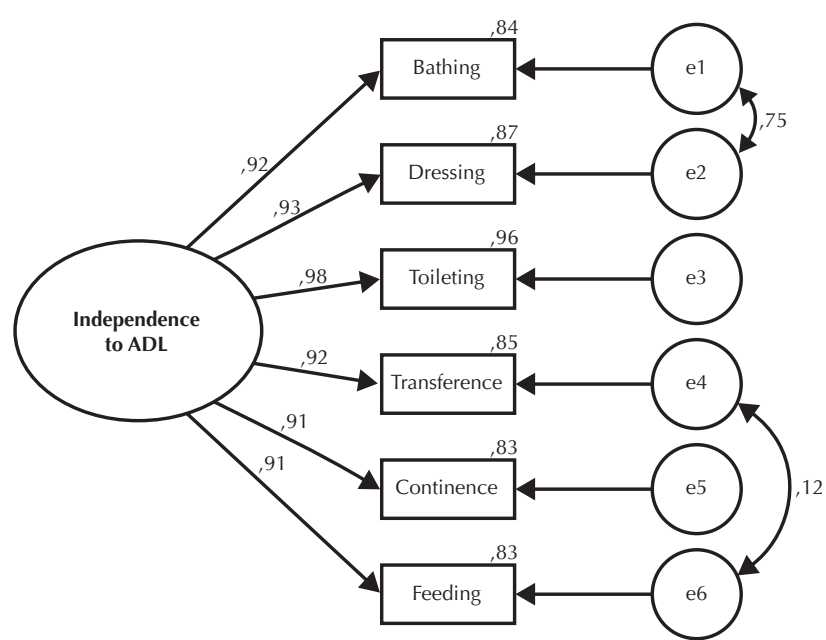

Figure 1 - Structural Equation Model path diagram for Katz Index (Subsample B; n=325) - São Paulo, SP, Brazil, 2005-2013.

Table 4 - Analysis of invariance between groups of cognitive decline - São Paulo, SP, Brazil, 2005-2013.

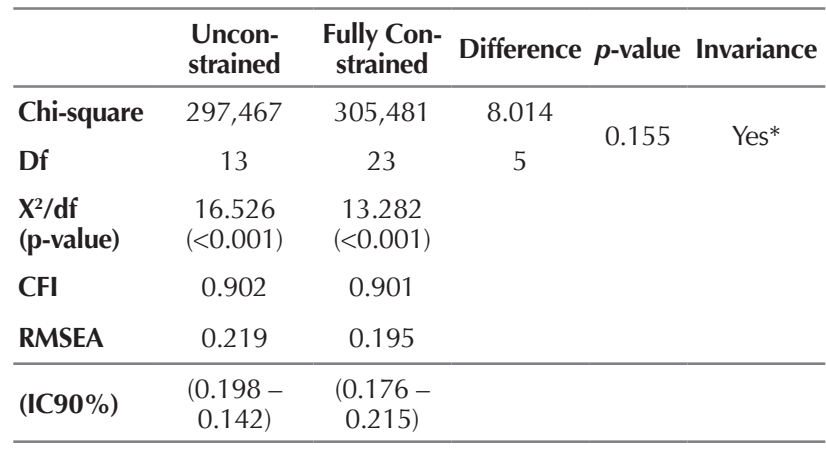

*Invariance assumed (groups are not different)

Note: (Subsample B; N=325).

\section{DISCUSSION}

Postmortem assessment of ADL to assist neuropathological studies is as important as it is during health care assistance, once it will contribute to the better understanding of the mechanisms of disease during the clinicopathological analysis. It is important to consider not only how to rate ADL, but also how it is assessed, once techniques related to measures will influence the estimative of impairment ${ }^{(25)}$.

In postmortem settings, ADL is very important as an indicative of disease progression. However, patients are not available to provide valid information or to perform activities to the assessment, as they are already dead. Therefore, other methods of gathering valid information are necessary, and the informant is an important source, as it is when the patient is alive. Thus, methods of investigation or health assessment by informants must be improved.

The Katz Index is a widely used instrument in different scenarios. It has been demonstrated that several studies used the Katz Index to assess ADL directly by patients or by proxies (informants) ${ }^{(25,27)}$. The reliability of the scale to assess ADL was synthetized in a review published in $2008^{(22)}$, and the cut-off points for the Katz Index to be considered as indicative of functional decline ${ }^{(27)}$ were demonstrated in 
another systematic review published in 2011. The item difficulty of the Katz Index was also analyzed by item-response theory, proving the hierarchical model of the scale ${ }^{(12)}$. In spite of all these previous studies, a comprehensive search on PubMed and other bases retrieved no research that aimed to analyze construct validity by factor analysis or reliability of the scale when applied by informants retrospectively. To the best of our knowledge, this original study was the first to analyze the construct validity of the Katz Index when applied to informants in postmortem settings to assist neuropathological studies.

The psychometric analysis of the Katz Index indicates that the instrument is valid and reliable to retrospectively assess basic activities of daily living in the elderly by informants, in postmortem settings, despite the existence of cognitive decline. However, careful analysis of data demonstrated the existence of multicollinearity ${ }^{(19)}$ indicating that there are items that could be revised. Psychometrically, if more than one item in the instrument measures the same phenomenon, both items are not necessary ${ }^{(19)}$. These indicatives of multicollinearity are probably because of the informant bias. In cognitive normal subjects, the informant may not be so aware of details in ADL performance, meanly when considering bathing and toileting. This may lead to variance in responses causing the collinearity to be more evident in subjects without cognitive decline. Further investigation of collinearity shall be done.

CFA confirmed that the instrument fit the hypothetical model, after the treatment of two co-variances ${ }^{(19,26)}$, reassuring the unidimensionality of the instrument, as indicated by the EFA. Invariance analyzes assured the fact that there is no need for normalization of the scale according to cognitive decline. This means that the Katz Index can be applied and scored the same way for both cognitive normal subjects and cognitively impaired ones.

Nowadays, total validity of an instrument is not measured by one single procedure. It is necessary to collect several evidences of validity to assume that the instrument is totally validated ${ }^{(28)}$. The present study analyzed evidences of construct validity and reliability but no evidence of criterion validity could be obtained. A diagnosis of multicollinearity was not performed to determine collinear items to be dropped, according to the existence of cognitive decline. These all could be considered limitations of the study.

Once data were collected in a postmortem setting, the assessment was performed entirely by an informant without the patient's input, which can be considered another limitation. We did not have a previous functional assessment to comparisons. The method of collecting postmortem data to assist a neuropathological study was previously validated by comparing the correspondence of information obtained by the caregiver to that obtained by the gold standard ${ }^{(20)}$. The results showed high specificity and sensitivity of the method for the diagnosis of dementia, normal cognition and function. Despite these results, further investigation of the psychometric properties of the Katz Index using the method of diagnosis correspondence between assessment of ADL by patients and informants is recommended.

The Katz Index was originally designed to assess ADL dichotomically, classifying the subject as being or not independent to $\mathrm{ADL}^{(7)}$. As recently highlighted, the scale is useful to detect independency and severe limitations. However, it is not sensitive to detect different levels of dependency and minor deviations from a previous assessment ${ }^{(29)}$. The three point scale used by the BBBABSG shall be useful in detecting levels of impairment between total independency and total dependency, once this scoring system transforms the index in an ordinal scale, instead of dichotomous. This should be considered for advanced practice in clinical settings.

Regardless the limitations, we shall probably assume that the results of the present study could be applied to samples of living patients, whenever it is necessary to assess ADL by knowledgeable informants (these results are only applicable if the informant is able to provide valid data). Once patients has dementia, the informant play an important role as a source of valid data ${ }^{(30)}$. Other else, there are situations when patients is unable to inform or demonstrate their abilities to perform ADL, because they are confused (with delirium) or unconscious. In such cases, the informant can be the only available source of data. Yet, the gerontologist should remember the limitations proper to the scale, regarding its strict ability to detect moderate impairment or discreet changes in function ${ }^{(29)}$, and the recall period in retrospective assessments. There is no consensus on the ideal recall period, but it is assumed that the longer the recall period, the higher the chance of imprecise information ${ }^{(25)}$. All these considerations should be addressed as implications for advanced practice.

Therefore, the Katz Index can be used to assess ADL in elderly subjects by informants, aiming to assist clinicopathological studies.

\section{CONCLUSION}

The Katz Index is a one-dimensional instrument that can be used to retrospectively assess ADL by informants, with construct validity and reliability, despite the presence of cognitive decline.

\section{RESUMO}

Objetivo: Analisar as evidências de validade de constructo do Índice de Katz para a avaliação retrospectiva das Atividades Básicas de Vida Diária (AbVD) por informantes, para apoiar estudos neuropatológicos no envelhecimento. Método: Por meio de estudo transversal foi analisada a capacidade funcional para as AbVD mensurada pelo Índice de Katz em 650 casos randomizados das bases de dados do Banco de Encéfalos Humanos do Grupo de Estudos em Envelhecimento Cerebral (BEHGEEC). A amostra foi particionada em duas subamostras para as análises ( $\mathrm{N}=325$, cada) e então estratificada de acordo com o comprometimento cognitivo determinado pelo Escore Clínico de Demência (CDR). Foram realizadas análise fatorial, de consistência interna e de invariância. Resultados: A 
análise fatorial evidenciou um instrumento unidimensional com ótima consistência interna, em todos os grupos. Ótimos índices de ajuste foram obtidos após o tratamento de duas covariâncias, indicando adequação da escala para avaliar AbVD por informantes. A escala é invariante para o comprometimento cognitivo, o que significa que pode ser usada em indivíduos com ou sem comprometimento cognitivo. Conclusão: O Índice de Katz apresenta validade de constructo para a avaliação retrospectiva das AbVD por informantes, com confiabilidade.

\section{DESCRITORES}

Atividades Cotidianas; Envelhecimento; Procurador; Psicometria; Estudos de Validação.

\section{RESUMEN}

Objetivo: Analizar las evidencias de validez de constructo del Índice de Katz para la evaluación retrospectiva de las Actividades Básicas de Vida Diaria (AbVD) por informantes para apoyar estudios neuropatológicos en el envejecimiento. Método: Por medio de estudio transversal se analizó la capacidad funcional para las AbVD mensurada por el Índice de Katz en 650 casos randomizados de las bases de datos del Banco de Encéfalos Humanos del Grupo de Estudios en Envejecimiento Cerebral (BEHGEEC). La muestra fue dividida en dos submuestras para los análisis $(\mathrm{N}=325$, cada) y luego estratificada de acuerdo con el compromiso cognitivo determinado por la Escala de Clasificación de la Demencia Clínica (CDR). Se hicieron análisis factorial, de consistencia interna y de invariancia. Resultados: El análisis factorial evidenció un instrumento unidimensional con excelente consistencia interna, en todos los grupos. Excelentes índices de ajuste fueron obtenidos después del tratamiento de dos covariancias, indicando la adecuación de la escala para evaluar AbVD por informantes. La escala es invariante para el compromiso cognitivo, lo que significa que se puede utilizarla en individuos con o sin compromiso cognitivo. Conclusión: El Índice de Katz presenta validez de constructo para la evaluación retrospectiva de las AbVD por informantes, con confiabilidad.

\section{DESCRIPTORES}

Actividades Cotidianas; Envejecimiento; Apoderado; Psicometría; Estudios de Validación.

\section{REFERENCES}

1. Alzheimer's Disease International (ADI); Policy Brief for Heads of Government. The Global Impact of Dementia 2013-2050 [Internet]. London; 2013 [cited 2015 May 28]. Available from: https://www.alz.co.uk/research/GloballmpactDementia2013.pdf

2. Prince M, Bryce R, Albanese E, Wimo A, Ribeiro W, Ferri CP. The global prevalence of dementia: a systematic review and meta-analysis. Alzheimers Dement. 2013;9(1): 63-75.

3. Alzheimer's Disease International (ADI). World Alzheimer Report 2014 - Dementia and Risk Reduction: an analysis of protective and modifiable factors [Internet]. London; 2014 [cited 2015 May 28]. Available from: http://www.alz.co.uk/research/world-report-2014

4. National Institute on Aging (NIA). National Institute of Health (NIH). Word Health Organization (WHO). Global Health and Aging [Internet]. Bethesda; 2011 [cited 2015 May 28]. Available from: http://www.who.int/ageing/publications/global_health.pdf

5. Alzheimer's Disease International (ADI). World Alzheimer Report 2010. The Global Economic Impact of Dementia [Internet]. London; 2010 [cited 2015 May 28]. Available from: http://www.alz.co.uk/research/world-report-2010

6. Gure TR, Kabeto MU, Plassman BL, Piette JD, Langa KM. Differences in functional impairment across subtypes of dementia. J Gerontol A Biol Sci Med Sci. 2010;65 (4):434-41.

7. Katz S, Ford AB, Moskowitz RW, Jackson BA, Jaffe MW. Studies of illness on the aged. The index of ADL: a standardized measure of biological and psychological function. JAMA. 1963;185:914-9.

8. Altman B. Definitions, concepts, and measures of disability. Ann Epidemiol. 2014;24(1):2-7.

9. Roering B, Hoeffken K, Pientka L, Wedding U. How many and which items of activities of daily living (ADL) and instrumental activities of daily living (IADL) are necessary for screening. Crit Rev Oncol Hematol. 2007;62(2):164-71.

10. White DK, Wilson JC, Keysor JJ. Measures of adult general functional status. Arthritis Care Res. 2011;63 Suppl 11:S297-307.

11. Reijneveld SA, Spijker J, Dijkshoorn H. Katz' ADL index assessed functional performance of Turkish, Moroccan, and Dutch elderly. J Clin Epidemiol. 2007;60(4): 382-8.

12. Gerrard P. The hierarchy of the activities of daily living in the Katz index in residents of skilled nursing facilities. J Geriatr Phys Ther. 2013;36(2):87-91.

13. Brorsson B, Asberg KH. Katz index of independence in ADL: reliability and validity in short-term care. Scand J Rehabil Med. 1984;16(3):125-32.

14. Gresham GE, Phillips TF, Labi ML. ADL status in stroke: relative merits of three standard indexes. Arch Phys Med Rehabil. 1980;61(8):355-8.

15. Katz S, Downs TD, Cash HR, Grotz RC. Progress in the development of the index of ADL. Gerontologist. 1970;10(1):20-30

16. Katz S, Akpom CA. Index of ADL. Med Care. 1976;14(5 Suppl):116-8.

17. Ferretti REL, Grinberg LT, Leite RP, Farfel JM, Pasqualucci CA, Nitrini R, et al. Banco de encéfalos humanos: uma ferramenta importante para o estudo do envelhecimento cerebral. Mundo Saúde. 2009;33(1):89-98.

18. Grinberg LT, Ferretti REL, Farfel JM, Leite REP, Pasqualucci CA, Rosemberg S, et al. Brain bank of the Brazilian ageing brain study group: a milestone reached and more than 1,600 collected brains. Cell Tissue Bank. 2007;8(2):151-62.

19. Hair JF Jr, Black WC, Babin BJ, Anderson RE. Multivariate data analysis. $7^{\text {th }}$ ed. London: Pearson; 2014.

20. Ferretti REL, Damin AE, Brucki SMD, Morillo LS, Perroco TR, Campora F, et al. Post-Mortem diagnosis of dementia by informant interview. Dement Neuropsychol. 2010;4(2):138-44. 
21. Wallace M, Shelkey M. Monitoring functional status in hospitalized older adults. Am J Nurs. 2008;108(4):64-71.

22. Canañero-Martínez M, Cabrero-Garcia J, Richart-Martiínez, Muñoz-Mendonza CL. Revisión estructurada de las medidas de actividades de la vida diaria en personas mayors. Rev Esp Geriatr Gerontol. 2008;43(5):271-83.

23. Kingston A, Collerton J, Davis K, Bond J, Robinson L, Jagger C. Losing the ability in activity of daily living in the oldest old: a hierarchic disability scale from the Newcastle 85+ study. Plos One. 2012;7(2):e31665.

24. Duarte YMO, Andrade CL, Lebrão ML. O Índex de Katz na avaliação da funcionalidade dos idosos. Rev Esc Enferm USP. $2007 ; 41(2): 317-25$.

25. Yang M, Ding X, Dong B. The Measurement of disability in the elderly: a systematic review of self-reported questionnaires. J Am Med Dir Assoc. 2014;15(2):150.e1-9.

26. Brown TA. Confirmatory factor analysis for applied research. $2^{\text {nd }}$ ed. New York: Guilford Press; 2015.

27. Buurman BM, van Munster BC, Korevaar JC, Haan RJ, Rooij SE. Variability in measuring (instrumental) activities of daily living functioning and functional decline in hospitalized older medical patients: a systematic review. J Clin Epidemiol. 2011; 64(6):619-27.

28. Furr RM, Bacharach VR. Psychometrics: an introduction. $2^{\text {nd }}$ ed. California: Sage; 2014.

29. Roedl KJ, Wilson LS, Fine JF. A systematic review and comparison of functional assessments of community-dwelling elderly patients. J Am Assoc Nurse Pract. 2015 May 11. [Epub ahead of print]

30. McKhanna GM, Knopmanc DS, Chertkowd H, Hymanf BT, Jack CR Jr, Kawash CH, et al. The diagnosis of dementia due to Alzheimer's disease: recommendations from the National Institute on Aging and the Alzheimer's Association workgroup. Alzheimers Dement. $2011 ; 7(3): 263-9$. 